\title{
Penggunaan Teknik Berpidato untuk Meningkatkan Keterampilan Berbicara Bahasa Sunda pada Perkuliahan Monolog
}

\author{
Dingding Haerudin, Nunuy Nurjanah, Danan Darajat, dan Farid Rizqi Maulana \\ Universitas Pendidikan Indonesia
}

\begin{abstract}
Corresponding authors. dingding.haerudin@upi.edu; nunuy.nurjanah@upi.edu; danan.darajat@upi.edu; faridriz10@student.upi.edu.

How to cite this article (in APA Style). Haerudin, D., Nurjanah, N., Darajat, D., \& Maulana, F.R. (2021). Penggunaan teknik berpidato untuk meningkatkan keterampilan berbicara bahasa Sunda pada perkuliahan monolog. Jurnal Pendidikan Babasa dan Sastra, 21(1),25-36.
\end{abstract} https://doi.org/10.17509/bs_jpbsp.v21i1.36655

History of article. Received: February 2021; Revised: March 2021; Published: April 2021

\begin{abstract}
Abstrak: Latar belakang penelitian ini adalah masih lemahnya keterampilan berbicara mahasiswa dalam bahasa Sunda. Untuk meningkatkan keterampilan berbicara dalam bahasa Sunda dapat dipelajari secara khusus dalam perkuliahan Monolog. Salah satu teknik dalam pembelajaran berbicara yang digunakan dalam perkuliahan Monolog adalah teknik berpidato. Sekaitan dengan latar belakang tersebut tujuan penelitian ini adalah untuk mengetahui kemampuan mahasiswa dalam berbicara setelah menggunakan teknik berpidato. Penelitian ini dilakukan dengan pendekatan kuantitatif. Metode penelitiannya menggunakan metode deskriptif analitik. Teknik pengumpulan datanya menggunakan teknik tes. Data yang diolah adalah skor tes kemampuan berbicara responden sebelum dan sesudah menggunakan teknik berpidato. Aspek-aspek kemampuan berbicara yang dinilai meliputi 1) struktur isi pembicaraan, 2) ekspresi, 3) bahasa yang digunakan, dan 4) kesesuaian antara topik dengan isi pembicaraan. Adapun yang menjadi respondennya adalah mahasiswa Departemen Pendidikan Bahasa Sunda Semester IV Angkatan 2018 salah satu perguruan tinggi di Bandung yang sedang mengikuti perkuliahan Monolog. Hasil yang diperoleh dari penelitian ini menunjukkan bahwa kemampuan berbicara mahasiswa sebelum menggunakan teknik berpidato (pre-test) masih rendah rata-rata 3.03 dan sesudah menggunakan teknik berpidato (post-test) meningkat rata-rata 3,45. Diperoleh peningkatan kemampuan berbicara sebelum dan sesudah menggunakan teknik berpidato sebesar 0,42 .
\end{abstract}

Kata kunci: bahasa Sunda; berpidato; kemampuan berbicara

\section{Use of Speech Techniques to Improve Sundanese Speaking Skills in Monologue Lessons}

\begin{abstract}
The background of this research is that the students' speaking skills in Sundanese are still weak. To improve speaking skills in Sundanese, it can be studied specifically in Monologue lessons. One of the techniques in learning to speak that is used in monologue lectures is the technique of making speeches. In connection with this background, the purpose of this study was to determine the ability of students to speak after using speech techniques. This research was conducted with a quantitative approach. The research method uses descriptive analytic method. The data collection technique uses a test technique. The data processed is the speaking skill test scores of respondents before and after using speech techniques. Aspects of speaking skills assessed include 1) the structure of the content of the conversation, 2) expression, 3) the language used, and 4) the suitability between the topic and the content of the conversation. The respondents were students of the Department of Sundanese Language Education Semester IV Class of 2018 in one of university in Bandung who were taking Monologue lessons. The results obtained from this study indicate that the students' speaking skilly before using the speech technique (pre-test) was still low on average 3.03 and after using the speech technique (post-test) increased by an average of 3.45. There was an increase in speaking skill before and after using speech techniques of 0.42 .
\end{abstract}

Keywords: Sundanese; speech; speaking skill 


\section{Pendahuluan}

Berbicara merupakan salah satu dari empat aspek keterampilan berbahasa lainnya di samping menyimak, membaca, dan menulis. Ketika berlangsungnya kegiatan berbicara pada saat itu pula menunjukkan proses berpikir seseorang. Chaer (2009) menyatakan bahwa berbahasa merupakan salah satu perilaku dari kemampuan manusia untuk bertindak (kemampuan berperilaku) dan berpikir. Faktor yang mempengaruhi keterampilan berbicara seseorang salah satunya adalah input yang diterima atau yang muncul dari lingkungan seperti lingkungan keluarga, lingkungan bermain, dan lingkungan pendidikan (Wahyono \& Farahsani 2017). Hal itu mengisyaratkan bahwa keterampilan bahasa diperoleh seseorang melalui kegiatan interaksi sosial dan kehidupan bermasyarakat.

Keterampilan berbicara seseorang juga dipengaruhi oleh input bahasa lisan ata proses verbal yang diterimanya dari hasil menyimak pada sebuah berinteraksi sosial. Keterampilan berbicara seseorang akan nampak dalam bertindak dan bertutur, seperti menjelaskan, bertanya, meminta, mengomentari, bercerita, atau pun bersumpah serapah.

Banyak anggapan berbicara dalam bahasa Sunda itu sulit. Berbicara dalam bahasa Sunda sebenarnya tidak sulit, asal memiliki kemauan untuk melatih dan membiasakan menggunakannya dalam kehidupan sehari-hari. Yang menjadi permasalahan adalah komunikasi masyarakat dalam kehidupan sehari-hari di lingkungannya tidak menggunakan bahasa Sunda. Begitu juga di lingkungan kampus, mereka belum seluruhnya memiliki keterampilan berbicara dengan baik. Dalam bahasa Sunda dikenal adanya undak-usuk basa atau tata karma berbahasa. Istilah lain untuk itu adalah kesantunan tersebut dapat dilakukan dengan cara membiasakan menggunakannya dalam kehidupan seharihari.

Ibda (2019) telah melakukan penelitian tindakan menggunakan program yang dinamakan SAMA-SAVI. Hasil penelitian tersebut menyatakan bahwa program yang digunakannya itu mampu meningkatkan keterampilan berbicara mahasiswa di di salah satu prodi yang diteliti secara signifikan, baik yang berkaitan dengan kemampuan pada aspek kebahasaan maupun nonkebahasaan.

Kegiatan berpidato merupakan salah satu sarana keterampilan berbicara, seperti dikemukakan Thornbury (2005) bahwa berpidato merupakan kegiatan berbicara yang dapat dilakukan oleh setiap orang dalam kegiatan sehari-hari.

Brown (2004) mengutarakan bahwa seseorang dapat disebut memiliki kompetensi berbicara apabila: 1) bisa meniru kata atau frasa atau mungkin kalimat yang disimak; 2) secara intensif mampu berintonasi dengan baik, seperti elemen prosodik, stres, ritme, titik; 3) mampu merespon atau menanggapi percakapan yang sangat singkat, salam standar dan obrolan ringan, permintaan sederhana dan komentar, dan sejenisnya; 4) dapat menjalin hubungan sosial dengan baik selama berinteraksi dengan lawan bicara; 5) dapat menjaga hubungan interpersonal selama menyampaikan fakta dari sebuah informasi; 6) cermat dalam menyampaikan informasi yang sulit dengan bahasa yang sederhana dan mudah dipahami pendengar sangat terbatas sangat banyak.

Untuk memperoleh keterampilan berbicara seperti yang dikemukakan di atas, dapat dilakukan dengan cara berlatih, salah satunya dengan teknik berpidato. Sekaitan dengan hal tersebut, permasalahan utama yang akan dijawab pada penelitian ini adalah bagaimanakah kemampuan berbicara mahasiswa Jurusan Pendidikan Bahasa Sunda sebelum dan sesudah menggunakan teknik berpidato?. Berdasarkan permasalahan tersebut maka tujuan penelitian ini adalah untuk mendeskripsikan kemampuan berbicara mahasiswa Jurusan Pendidikan Bahasa Sunda sebelum dan sesudah menggunakan teknik berpidato

\section{Metode}

Penelitian ini menggunakan metode deskriptif analisis. Metode ini digunakan untuk menggambarkan data yang terkumpul setelah dianalisis berdasarkan rumusan permasalahan tujuan penelitian. Teknik 
pengumpulan datanya menggunakan teknik tes. Data kemampuan berpidato diperoleh dengan cara melakukan preetes dan posttes. Preetest dilakukan untuk mengetahui kemampuan berbicara sebelum memperoleh perlakuan, sedangkan postets dilakukan untuk mengetahui kemampuan berbicara setelah memperoleh perlakuan. Adapun materi perlakuan yang diberikan kepada responden berkenaan dengan teknik berpidato.

Langkah-langkah yang ditempuh selama memberikan perlakuan kepada responden mengenai teknik berpidato meliputi: 1) responden memperoleh penjelasan tentang struktur pidato yang mencakup pembukaan, isi, dan penutup; bahasa yang mencakup struktur kata, kalimat, dan kosakata; topik yang dibicarakan; dan ekspresi yang meliputi gesture dan mimik, volume, dan intonasi; 2) responden diperintah mencari satu topik yang mereka kuasai untuk dijadikan bahan pidato selama dua menit; 3) responden diberi kesempatan untuk mempersiapkan materi yang akan dipidatokan sesuai dengan topik yang dipilihnya; 4) responden dipersilakan untuk berpidato mengenai materi yang dipilihnya masing-masing, yang direkam menggunakan kamera gawai/gadget atau telepon genggam/hp.

Data yang diolah adalah kemampuan berbicara jenis teks pidato dari hasil preetest dan posttes. Alat yang digunakan selama pengumpulan datanya adalah telepon genggam atau hand phone yang dimiliki oleh setiap responden. Prosedur pengumpulan data yang dilakukan yaitu peneliti menerima hasil rekaman pidato dari setiap responden. Responden yang menjadi sumber datanya yaitu mahasiswa Departemen Pendidikan Bahasa Sunda semester IV Angkatan 2018 pada salah satu perguruan tinggi di Bandung, yang sedang mengikuti perkuliahan Monolog.
Instrumen yang digunakan yaitu lembar penilaian kemampuan berpidato, yang di dalamnya meliputi struktur pidato, ekspresi berpidato, bahasa yang digunakan, dan kesesuaian topik yang diberikan dengan yang diucapkan.

Langkah-langkah yang ditempuh dalam penelitian ini meliputi: (1) menyeleksi dan memverifikasi setiap data yang ditemukan; (2) mengklasifikasi; (3) menganalisis; (4) mendeskripsikan; dan (5) menyusun dalam bentuk laporan penelitian.

\section{Hasil dan Pembahasan}

Data yang diperoleh dalam ini meliputi kemampuan berbicara sebelum menggunakan teknik pidato, kemampuan berbicara sesudah menggunakan teknik pidato, dan perbedaan kemampuan berbicara sebelum dan sesudah menggunakan teknik berpidato. Adapun Aspek-aspek kemampuan berbicara yang dideskripsikan meliputi aspek struktur penyampaian, bahasa yang digunakan, kesesuaian isi dan topik, serta ekspresi. Untuk melihat dan menentukan tingkat kemampuan responden, digunakanlah Kriteria Ketuntasan Minimal (KKM), yaitu a) Nilai $\geq 3,0$ dianggap mampu dan b) Nilai $\leq 3,0$ dianggap belum mampu.

\section{Kemampuan Berbicara Sebelum Menggunakan Teknik Pidato}

Kemampuan berbicara responden sebelum menggunakan teknik berpidato diperoleh berdasarkan hasil pre-test rata-rata 3.03. Nilai tersebut melampaui KKM 3.0 artinya sudah mampu, namun belum menggembirakan karena berada pada ambang batas kemampuan minimal dan masih perlu ditingkatkan.

Dari 40 responden yang dianggap telah mampu ada $30(70 \%)$, sedangkan $10(30 \%)$ responden lainnya belum mampu. Seperti terlihat pada diagram 1 berikut. 


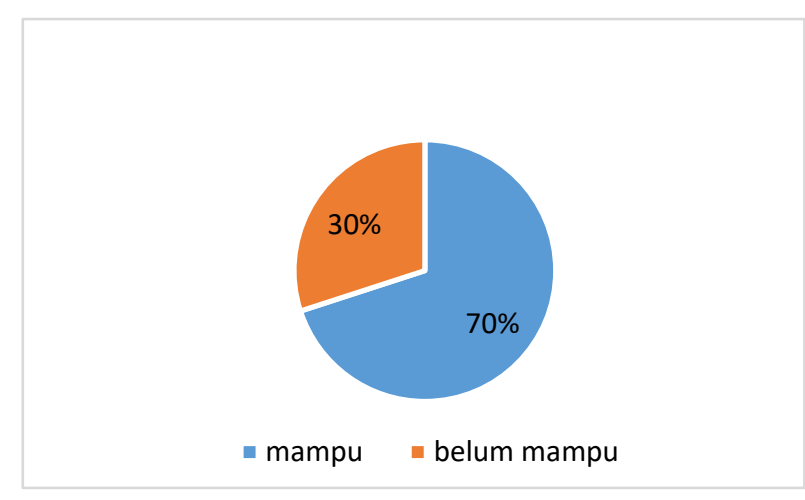

\section{Diagram 1}

Kemampuan Berbicara Sebelum Menggunakan Teknik Berpidato

Skor kemampuan berbicara responden pada aspek struktur rata-rata 3,20. Angka berada di atas KKM. Namun masih ada 5 $(12,5 \%)$ responden kemampuan dalam merangkai pembicaraan di bawah KKM.

Skor kemampuan berbicara pada aspek bahasa rata-rata 2,85 berada di bawah KKM. Artinya penggunaan bahasa Sunda responden ketika berbicara masih rendah. Diketahui ada $9(22.5 \%)$ responden memiliki kemampuan penggunaan bahasa Sunda masih rendah.
Skor kemampuan berbicara pada aspek topik memiliki rata-rata 2,73. Artinya responden belum seluruhnya mampu menguasai topik. Diketahui ada 10 (30\%) responden yang belum mampu berbicara sesuai dengan topik yang dipilihnya.

Skor kemampuan berbicara pada aspek ekspresi memiliki rata-rata 3,23. Angka berada di atas KKM. Namun masih ada 6 $(15 \%)$ belum memiliki kemampuan berekspresi dengan baik ketika berbicara. Selanjutnya bisa dilihat pada diagram 2 berikut ini.

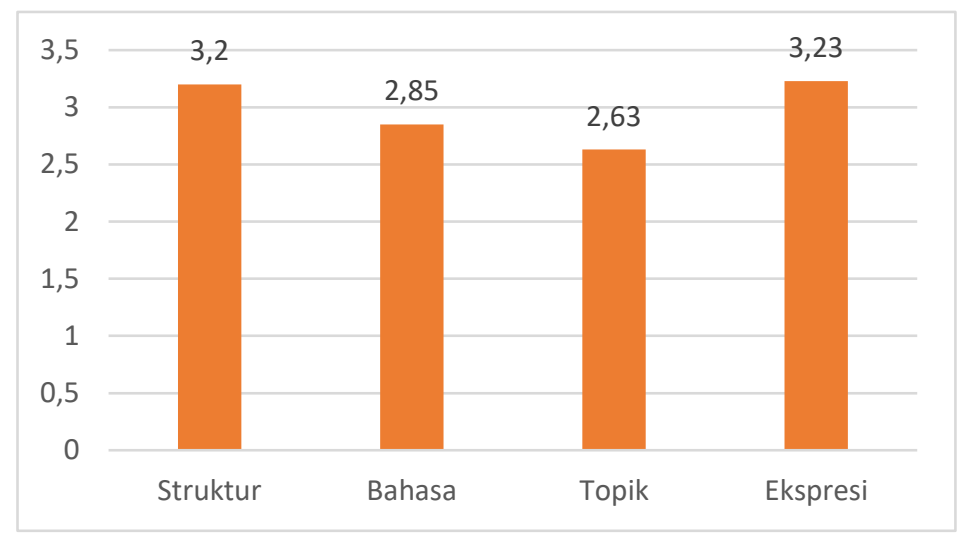

\section{Diagram 2}

Kemampuan Setiap Aspek Berbicara Sebelum Menggunakan Teknik Berpidato

Pada diagram di atas dapat diketahui bahwa kemampuan berbicara responden pada aspek ekspresi paling tinggi yaitu 3,23, diikuti untuk aspek struktur pembicaraan 3,20, kemudian aspek penggunaan bahasa 2,85 , serta aspek kesesuaian topik dengan isi pembicaraan 2,63.

\section{Kemampuan Berbicara Sesudah Menggunakan Teknik Pidato}

Kemampuan berbicara responden sesudah menggunakan teknik pidato diperoleh berdasarkan hasil post-test rata-rata 3,45. Nilai tersebut berhasil melampaui KKM 3,0 dan berada di atas nilai pre-test 3,03. Hal itu menunjukkan bahwa kemampuan 
berbicara responden setelah menggunakan teknik pidato meningkat. Persentase kemampuan mahasiswa dalam keterampilan berbicara bisa dilihat pada diagram 3 berikut ini.

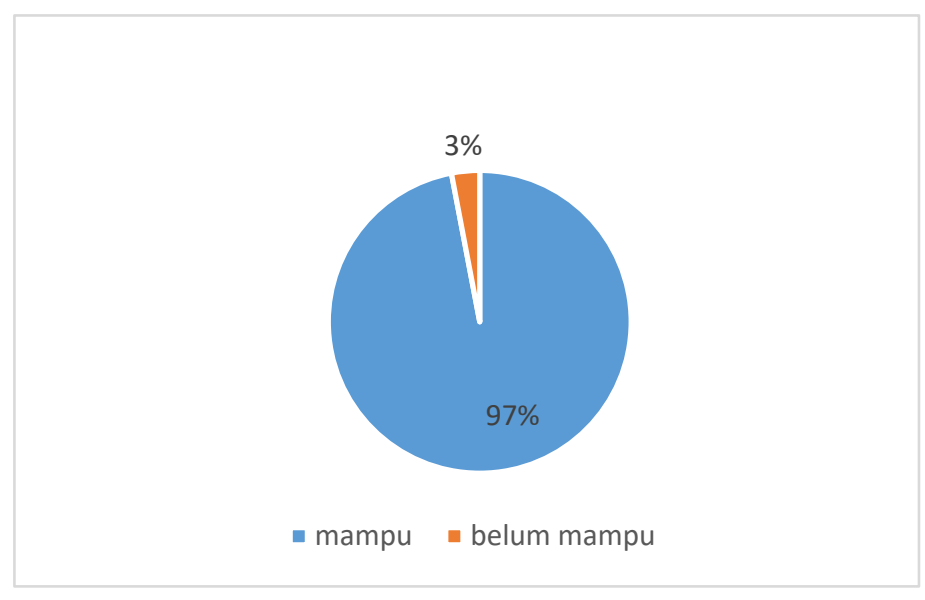

\section{Diagram 3}

Persentase Kemampuan Berbicara Sesudah Menggunakan Teknik Pidato

Skor kemampuan berbicara responden pada aspek struktur setelah menggunakan teknik berpidato rata-rata 3,63.

Skor kemampuan berbicara responden dilihat dari aspek penggunaan bahasa setelah menggunakan teknik berpidato rata-rata 3,25.

Skor kemampuan berbicara responden dilihat dari aspek kesesuaian isi dengan topik setelah menggunakan teknik berpidato ratarata 3,15 .

Skor kemampuan berbicara dilihat dari aspek ekspresi setelah menggunakan teknik berpidato rata-rata 3,75 .

Untuk lebih jelasnya, bisa dilihat pada diagram 4 berikut ini.

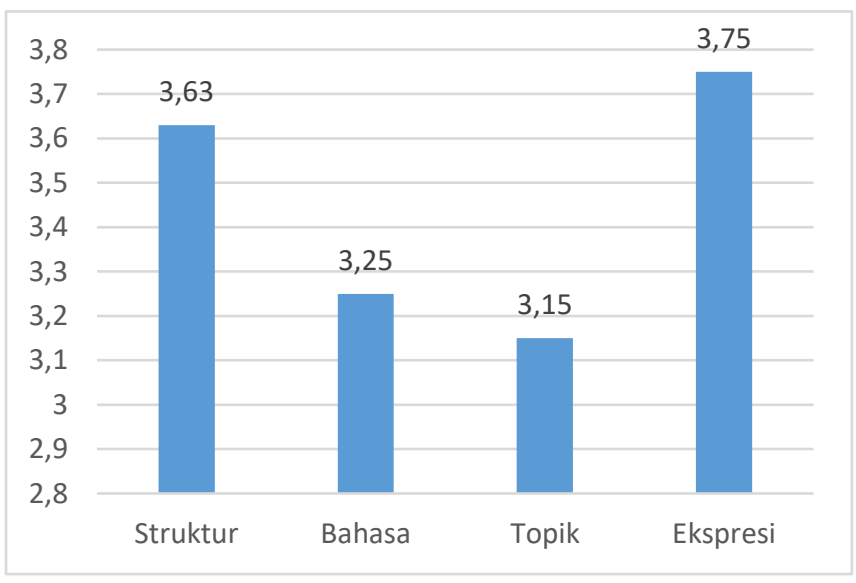

\section{Diagram 4}

Kemampuan Setiap Aspek BerbicaraSetelah Menggunakan Teknik Berpidato

Pada diagram di atas dapat diketahui bahwa kemampuan berbicara responden pada aspek berekspresi paling tinggi yaitu 3,75, diikuti aspek struktur pembicaraan 3,63, kemudian aspek penggunaan bahasa 3,25, serta aspek kesesuaian topik dengan isi pembicaraan 3,15. 


\section{Perbedaan Kemampuan Berbicara \\ Sebelum dan Sesudah Menggunakan Teknik Berpidato \\ Perbedaan kemampuan berbicara} responden sebelum dan sesudah menggunakan teknik berpidato bisa dilihat perbedaan rata-rata yang cukup signifikan di antara data sebelum dan sesudah menggunakan teknik berpidato. Kemampuan berbicara responden baik sebelum maupun sesudah menggunakan teknik berpidato berdasarkan tabel data di atas menunjukkan nilai di atas KKM. Kemampuan berbicara sebelum menggunakan teknik berpidato ratarata telah melampaui capaian ketuntasan minimal 3,03. Rata-rata itu pun meningkat setelah menggunakan teknik berpidato yaitu 3,45 .

Perbedaan rata-rata berdasarkan aspek yang dinilai bisa dilihat dan tersaji pada diagram berikut ini.

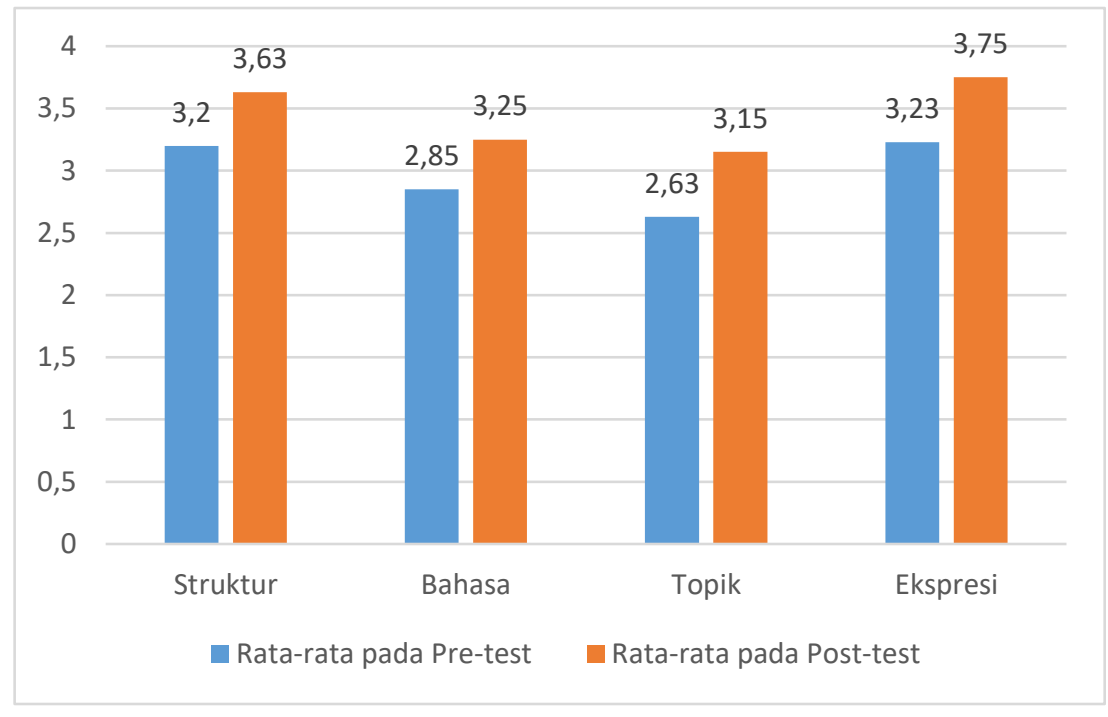

\section{Diagram 5}

Perbedaan Kemampuan Berbicara Berdasarkan Aspek

Berdasarkan diagram di atas, di bawah ini selanjutnya dideskripsikan perbedaan kemampuan setiap aspek yang meliputi struktur, bahasan, topik, dan ekspresi.

\section{Perbedaan Kemampuan Aspek Penyusunan Struktur Pembicaraan}

Kemampuan berbicara responden dilihat dari aspek struktur setelah menggunakan teknik berpidato rata-rata 3,63 berada di atas nilai rata-rata sebelum setelah menggunakan teknik berpidato 3,20. Hal itu menunjukkan bahwa keterampilan berbicara responden pada aspek struktur pembicaraan setelah menggunakan teknik berpidato meningkat 0,43 .

Kemampuan responden dalam mengorganisasi aspek struktur pidato pada umumnya telah baik. Beberapa catatan yang ditemukan berkaitan dengan aspek pengorganisasian struktur berpidato dalam penelitian ini di antaranya (1) ada responden secara mengawali pidato dengan mengucapkan salam, menyampaikan penghormatan kepada yang hadir, memuji syukur kepada yang Mahakuasa dan berselawat kepada baginda Nabi Muhammad Saw. Isi pidato yang dibahas sesuai dengan topik, serta di akhir pidato ditutup dengan menyampaikan kesimpulan, diikuti dengan saran-saran untuk orang lain. (2) Sebagian responden lainnya memulai berpidato dengan mengucapkan salam dan menyampaikan puji syukur, tetapi tidak menyampaikan penghormatan kepada yang hadir. (3) Sebagian responden lainnya tidak menyampaikan penghormatan kepada yang hadir dan Isi pidato yang dibahas kurang sesuai dengan topik. (4) Sebagian kecil responden lainnya tidak menyampaikan penghormatan, tidak menyampaikan puji syukur, isi pidato kurang sesuai yang dibahas 
sesuai dengan topik, dan pidato ditutup dengan tidak menyampaikan kesimpulan, diikuti dengan saran-saran untuk orang lain.

Mengawali berbicara, responden pada umumnya mengucapkan salam. Data ucapan salam cukup bervariasi, di antaranya sebagai berikut.
(1) Assalamualalaikum
(2) Assalamualaikum warahmatullabi wabarakaatub
(3) Wilujeng énjing
(4) Sampurasun

Di samping ucapan salam, responden juga menyampaikan ucapan terima kasih dan ucapan puji syukur serta selawat kepada baginda Nabi Muhammad Saw. Ungkapan rasa syukur dan selawat rata-rata menggunakan bahasa Arab dan ada pula yang dilengkapi dengan bahasa Sunda, seperti data berikut ini.

Data ucapan terima kasih:

(1) ngahaturkeun nubun ka panata acara anu parantos masiban waktos ka simkuring kanggo cumarios dina ieu kasempetan.

(2) Simkuring ngahaturkeun wilujeng sumping ka para tamu anu parantos ngahadiran ieu acara.

Hamdalah berbahasa Sunda:

(1) Puji sinareng sukur urang sanggakeun ka gusti nu maha suci anu parantos maparin kanikmatan ka urang sadayana tur tiasa patepung lawung paamprok jonghok dina ieu kasempetan.

Hamdalah berbahasa Arab:

(1) Alhamdulillabi robbil aalamiin Selawat:

(1) Puji sinareng sukur mangga urang panjatkeun ka Kangjeng Nabi Mubammad Saw. Miwah ka para sahabatna, ka para umatna, tug nepi ke urang sadayana.

\section{Perbedaan Kemampuan Aspek Penggunaan Bahasa}

Kemampuan berbicara responden dilihat dari aspek penggunaan bahasa setelah menggunakan teknik berpidato rata-rata 3,25 berada di atas nilai rata-rata sebelum setelah menggunakan teknik berpidato 2,85 . Hal itu menunjukkan bahwa kemampuan berbicara responden pada aspek bahasa yang digunakan setelah menggunakan teknik berpidato meningkat 0,40 .

Setelah memperoleh perlakuan teknik berpidato umumnya responden telah mampu menggunakan bahasa Sunda yang cukup bervariasi. Namun sebagian responden masih melakukan pengulangan kata yang sama saat berbicara, seperti penggunaan kata "lalu, kemudian, dan selanjutnya".

Di samping itu, masih ada sebagian yang masih menggunakan kosa kata yang dipengaruhi bahasa Indonesia (kamalayon), seperti kata "panjatkeun, ngenalkeun, ngaminimalisir, santai, sahingga, pembawaan" seperti pada ungkapan kalimat berikut:

(R5) ... langkung ti payun urang [panjatkan] puji jeung sukur ka hadirat Allah Swt....

Kata yang tepat pada konteks kalimat tersebut adalah sebagai berikut:

... langkung ti payun mangga urang [muji sukur] ka Allah Swt.

atau:

... langkung ti payun mangga urang [nyanggakeun] puji sukur ka Allah Swt.

(R7) ... sateuacanna simkuring badé [ngenalkeun] beula....

Sebaiknya sebagai berikut:

... sateuacanna simkuring badé

[nepangkeun] beula ....

Setelah memperoleh perlakuan teknik berpidato, sebagian besar responden memiliki kejelian dalam memilih dan menempatkan kata. Hanya sebagian kecil responden yang masih tertukar dalam memililih kata, seperti kata nyarios, ngupingkeun, (untuk orang lain) seharusnya nyanggem atau sumanggem.

(R12) Simkuring badé [nyarioskeun] perkawis...

Dalam konteks ini sebaiknya menyampaikan sebagai berikut:
Simkuring badé
perkawis... 
(R18) ... hadéna mah leuwih [santai] [pembawaanana] [sahingga] bisa [ngaminimalisir] kasalahan....

Untuk ungkapan kalimat di atas, sebaiknya baik struktur maupun katanya seperti berikut:

\section{Hadéna mah [sing] [antaré] [nepikeunana], [sangkan] [teu loba teuing] kasalahan.}

\section{Perbedaan Kemampuan Aspek Kesesuaian Topik dan Isi}

Kemampuan berbicara responden dilihat dari aspek kesesuaian isi dengan topik setelah menggunakan teknik berpidato ratarata 3,15 berada di atas nilai rata-rata sebelum menggunakan teknik berpidato 2,75. Hal itu menunjukkan bahwa kemampuan berbicara responden pada aspek kesesuaian topik dengan isi setelah menggunakan teknik berpidato meningkat 0,40 .

Setelah memperoleh perlakuan menggunakan teknik berpidato pada umumnya responden telah mampu memahami materi yang dibicarakan. Materi yang dibicarakan mereka adalah materi yang sama dengan sebelum perlakuan. Sebelum perlakuan masih banyak responden yang belum menguasai dan menyampaikan materi sesuai dengan topik. Namun setelah memperoleh perlakuan, mereka mampu melengkapi materi dengan baik yang sesuai dengan topik.

Materi yang disampaikan responden setelah memperoleh perlakuan teknik berpidato pada umumnya mengandung informasi yang bermanfaat bagi pendengar. Mereka tidak sekadar berbicara, tetapi mampu menyampaikan materi yang berbobot yang didasari referensi dari hasil membaca. Mereka telah berupaya mamahami materi yang dibicarakan dengan baik.

\section{Perbedaan Kemampuan Aspek Ekspresi}

Kemampuan berbicara dilihat dari aspek ekspresi setelah menggunakan teknik berpidato rata-rata 3,75 berada di atas nilai rata-rata sebelum menggunakan teknik berpidato 3,23. Hal itu menunjukkan bahwa kemampuan berbicara responden pada aspek ekspresi setelah menggunakan teknik berpidato meningkat 0,52 .

Ekspresi responden ketika berbicara setelah memperoleh perlakuan teknik berpidato pada umumnya baik. Mereka mampu menguasai audiens, berbicara tenang, membagi pandangan, tidak monoton, dan percaya diri. Begitu juga yang berkaitan dengan intonasi, naik turunnya suara, kejelasan pelafalan, dan mimik telah mereka kuasai dengan baik.

Berdasarkan hasil penelitian, diketahui bahwa kemampuan berbicara bahasa Sunda responden setelah menggunakan teknik berpidato rata-rata meningkat. Peningkatan kemampuan berbicara responden pada setiap aspek. Peningkatan yang paling menonjol pada aspek eskpresi yaitu dari 3,23 menjadi 3,75 (meningkat 0,52) dan aspek kesesuaian isi dengan topik dari 2,63 menjadi 3,15 (meningkat 0,52), diikuti aspek struktur pembicaraan dari 3,2 menjadi 3,63 (meningkat 0,43), serta aspek bahasa dari 2,85 menjadi 3,25 (meningkat 0,40).

Peningkatan pada aspek ekspresi menggambarkan bahwa responden telah memperoleh kepercayaan diri, memiliki ketenangan, dan tidak kaku. Kondisi tersebut mendukung kelancaran menyampaikan materi. Pada umumnya materi yang disampaikan telah sesuai dengan topik yang dipilihnya. Temuan penelitian ini sejalan dengan hasil penelitian Sudarminah (2009) yang menyatakan bahwa untuk meningkatkan kelancaran berbicara memerlukan strategi. Pemilihan strategi yang tepat memengaruhi peserta didik menjadi antusias, tidak malu, lancar berbicara, tidak takut, lebih meyakinkan, dan konsentrasi pada pembelajaran. Hal senada disampaikan juga oleh Romadlon (2016) dan Patiung, dkk. (2015) bahwa dengan menggunakan strategi atau teknik yang tepat, peserta didik menjadi aktif dan berani serta percaya diri dalam menyampaikan pendapat. Di samping itu, mereka juga memiliki pengalaman yang mengesankan. 


\section{Kemampuan Aspek Struktur}

Kemampuan responden pada aspek struktur pembicaraan atau struktur berpidato dalam penelitian ini juga mengalami peningkatan. Mereka telah mampu mengawali pembicaraan dengan pembukaan yang baik, mengucapkan salam, menyapa hadirin, menyampaikan penghormatan. Demikian juga pada bagian isi, materi pembicaraan disampaikan dengan baik dan runtun. Isi yang dibahas cukup menarik dan telah mengena, juga sesuai dengan topik. Di akhir pembicaraan ditutup dengan menyampaikan kesimpulan dan kata salam.

Keruntunan berbicara responden dari mulai pembukaan sampai penutupan menandakan sudah terbentuknya konsep berpikir. Responden telah memiliki kemampuan merencanakan materi yang akan disampaikan dan mampu memilah-milah bahan pembicaraan yang akan disampaikan dalam bagian pembukaan, isi, serta bagian penutup. Temuan ini sejalan dengan hasil penelitian yang dilakukan Romadlon (2016), bahwa pembicara yang cakap mampu menyampaikan materi dengan runtut dan baik. Hal itu penting dimiliki seseorang dalam berpidato agar menarik bagi pendengarnya. Materi yang disampaikan di samping bermanfaat juga dapat dipertanggungjawabkan. Isi materi yang sesuai topik dapat membina keharmonisan pembicara dan pendengar.

\section{Kemampuan Aspek Bahasa}

Kemampuan responden pada aspek bahasa dalam penelitian ini juga mengalami peningkatan. Materi pembicaraan disampaikan dengan bahasa Sunda yang baik. Namun demikian masih ada terselip menempatkan kata-kata pengaruh bahasa lainnya. Hal ini tidak mudah untuk menghilangkannya. Berdasarkan angket ada sebagian responden yang kesehariannya lebih dominan menggunakan bahasa Indonesia. Temuan ini sejalan dengan hasil penelitian Hidayat dan Setiawan (2015) yang menyatakan bahwa sikap dan kebiasaanya sehari-hari akan terbawa ketika seseorang berbicara dalam bahasa yang lainnya.
Ditemukan ketika responden berbicara dalam bahasa Sunda terselip bahasa Indonesia atau bahasa lainnya. Terjadinya hal demikian dikarenakan keterbatasan waktu berpikir saat berbicara, sehingga terjadilah campur kode. Akan tetapi hal demikian berdasarkan temuan dari hasil penelitian yang dilakukan Simatupang, dkk. (2018) adalah interferensi jenis campur kode bisa merupakan strategi pembicara untuk mendekatkan diri dengan pendengar atau agar mereka lebih memahami informasi yang disampaikan.

\section{Kemampuan Aspek Kesesuaian Isi dan Topik}

Kemampuan responden meningkat juga pada aspek kesesuaian isi dengan topik. Mereka telah mampu menyesuaikan materi dengan topik yang disediakan. Hanya sebagian kecil yang belum memiliki kemampuan pada hal tersebut. Berdasarkan angket, hal itu terjadi karena responden tidak mempersiapkannya dengan matang, mereka kurang membaca referensi. Temuan ini senada dengan hasil penelitian yang dilakukan Darmuki dan Hariyadi (2019) bahwa kurangnya kemampuan berbicara disebabkan kurangnya menggali informasi. Oleh sebab itu, agar seseorang memiliki kemampuan berbicara ia harus rajin membaca materi yang akan dibicarakan.

Selama tampil menggunakan teknik berpidato responden tampak nyaman berbicara. Mereka mampu menyampaikan gagasan yang sesuai dengan topik. Materi yang disampaikan sarat dengan ide-ide cemerlang dan pikiran-pikiran kritis yang dibutuhkan pendengar. Hal ini sejalan dengan pendapat Suleimenova (2013) bahwa sangat penting menggiring kemampuan berpikir anak didik agar suasana pembelajaran tercipta secara kondusif. Responden pun termotivasi dengan penerapan teknik pidato ini, karena mereka digiring pada suasana berkompetisi dengan sesama temannya. Teknik berpidato ini juga mampu meningkatkan kepercayaan diri responden dalam berbicara. Temuan ini senada dengan hasil penelitian Fitri, dkk (2018) yang menyatakan bahwa pemberian 
motivasi itu akan meningkatkan rasa optimis bagi seseorang.

\section{Kemampuan Berekspresi}

Kemampuan berekspresi responden dalam penelitian ini juga meningkat. Mereka telah berupaya berbicara dengan dinamis, di antaranya didukung dengan bahasa tubuh atau gesture. Temuan ini sejalan dengan pendapat Akhadiah et al., (1992) bahwa ekspresi atau mimik merupakan aspek nonkebahasaan dapat mendukung terjalinnya komunikasi dengan baik. Bahasa Sunda yang digunakan responden selama berbicara mengalir dan tidak kaku. Mereka berupaya menggerakkan anggota tubuh, menatap, dan melemparkan senyuman kepada pendengar. Sekaitan dengan kemampuan berekspresi responden Setyonegoro (2014) dan Tarigan (1991) menyatakan bahwa keterampilan berbicara itu pada hakikatnya keterampilan menyampaikan pesan. Agar audiens memahami pesan yang disampaikan, maka pembicara harus mampu berekspresi dengan baik, di antaranya lagu kalimat.

\section{Simpulan}

Berdasarkan hasil penelitian, dapat disimpulkan bahwa kemampuan berbicara responden sebelum menggunakan teknik berpidato dari hasil pre-test rata-rata 3.03. Nilai tersebut melampui KKM 3.0. Namun masih ada beberapa responden dengan aspek yang masih dianggap kurang mampu, yaitu sebanyak 10 responden atau 30\% dari sebanyak 40 responden. Kemampuan pada setiap aspek, yaitu aspek struktur rata-rata 3,20 , aspek bahasa rata-rata 2,85 , aspek topik rata-rata 2,73, dan aspek ekspresi rata-rata 3,23.

Kemampuan berbicara responden sesudah menggunakan teknik berpidato dari hasil post-test rata-rata 3,45. Nilai tersebut melampaui KKM 3,0 dan berada di atas nilai pre-test 3,03. Hal itu menunjukkan bahwa kemampuan berbicara responden setelah menggunakan teknik pidato meningkat. Kemampuan berbicara responden pada aspek struktur rata-rata 3,63, kemampuan pada aspek penggunaan bahasa rata-rata 3,25, kemampuan pada aspek kesesuaian isi dengan topik rata-rata 3,15, kemampuan pada aspek ekspresi rata-rata 3,75.

Peningkatan kemampuan berbicara sebelum dan sesudah menggunakan teknik berpidato adalah 0,42, yaitu dari 3,03 menjadi 3,45. Kemampuan berbicara responden pada setiap aspek juga meningkat, yaitu aspek struktur rata-rata 3,63 yang sebelumnya 3,20 meningkat 0,43 . Aspek penggunaan bahasa rata-rata 3,25 yang sebelumnya 2,85 meningkat 0,40 . Aspek kesesuaian isi dengan topik rata-rata 3,15 yang sebelumnya 2,75 meningkat 0,40. Aspek ekspresi rata-rata 3,75 yang sebelumnya 3,23 meningkat 0,52.

Peningkatan pada aspek ekspresi menggambarkan bahwa responden telah memperoleh kepercayaan diri, memiliki ketenangan, dan tidak kaku. Kondisi tersebut mendukung kelancaran menyampaikan materi. Demikian juga pada aspek struktur pembicaraan atau struktur berpidato, responden telah mampu mengawali pembicaraan dengan pembukaan yang baik, mengucapkan salam, menyapa hadirin, menyampaikan penghormatan. Pada aspek isi, materi pembicaraan disampaikan dengan baik dan runtun. Isi yang dibahas cukup menarik dan telah mengena, juga sesuai dengan topik. Materi pembicaraan disampaikan dengan bahasa Sunda yang baik.

\section{Daftar Rujukan}

Akhadiah, S., et al. (1992/1993). Bahasa Indonesia 1. Jakarta: Departemen Pendidikan dan Kebudayaan Direktorat Jendral Pendidikan Tinggi Proyek Pembinaan Tenaga Kependidikan.

Brown, D. (2004). Language Assessment Principle and Classroom Practices. San Francisco State University: Longman.

Chaer, A. (2009). Psikolinguistik Kajian Teoritik. Jakarta: Rineka Cipta.

Darmuki, A., \& Hariyadi, A. (2019). Peningkatan Keterampilan Berbicara Menggunakan Metode Kooperatif Tipe Jigsaw pada Mahasiswa PBSI Tingkat IB IKIP PGRI Bojonegoro Tahun

Akademik 
2018/2019. KREDO: Jurnal Ilmiah Bahasa dan Sastra, 2(2), 256-267.

Fitri, E., Zola, N., \& Ifdil, I. (2018). Profil kepercayaan diri remaja serta faktorfaktor yang mempengaruhi.JPPI Jurnal Penelitian Pendidikan Indonesia), 4(1), $1-5$. https://doi.org/10.29210/02017182

Hidayat, R., \& Setiawan, T. (2015). Interferensi Bahasa Jawa ke dalam Bahasa Indonesia pada Keterampilan Berbicara Siswa Negeri 1 Pleret, Bantul. LingTera, 2(2), 156- 168. https://doi.org/10.21831/lt.v2i2.7374

Ibda, H. (2019). Peningkatan Keterampilan Berbicara pada Mahasiswa melalui Program SAMA SAVI (Satu Mahasiswa Satu Video). Jurnal Pena Indonesia, 5(1), 1-18.

Patiung, D., Tolla, A., Anshari, A., \& Dolla, A. (2015).The Study of Learning Speaking Skills Based on Communicative Approach. Journal of Language Teaching and Research, 6(5), 1093-1098.

http://dx.doi.org/10.17507/jltr.0605. 23.

Romadlon, F. N. (2016). Communication Strategies in the Conversations Between Indonesian University Students and A Native Speaker. Vision: Journal for Language and Foreign Language Learning, 5(1), 5-26.

Setyonegoro, A. (2014). Kolaborasi Teori Fenomenologis dan Teori Berbicara dalam Pembelajaran Berbicara dengan Pendekatan Saintifik. Pena: Jurnal Pendidikan Bahasa dan Sastra, 3(2).

Simatupang, R. R., Rohmadi, M., \& Saddhono, K. (2018). Alih Kode dan Campur Kode Tuturan di Lingkungan Pendidikan. LingTera, 5(1), 1-9. https://doi.org/10.21831/lt.v5i1.1919 $\underline{8}$

Sudarminah, S. (2009). Upaya Peningkatan Pembelajaran Berbicara dengan Model Pembelajaran Gambar Seri untuk Siswa Kelas VIII SMP Negeri 6 Semarang. Media Penelitian Pendidikan: Jurnal Penelitian dalam Bidang Pendidikan dan

Pengajaran, http://dx.doi.org/10.26877/mpp.v3i2 .292 .

Suleimenova, Z. (2013). Speaking Anxiety in a Foreign Language Classroom in Kazakhstan. Procedia-Social and Behavioral Sciences, 93, 1860-1868. https://doi.org/10.1016/j.sbspro.201 3.10.131.

Tarigan, H.G. (1991). Keterampilan Berbicara. Jakarta: Bumi Aksara.

Thornbury, S. (1994). How to teach speaking. Jakarta: Kesainc Blanc.

Wahyono, T., \& Farahsani, Y. (2017). Penerapan pendekatan proses untuk meningkatkan keterampilan berbicara bahasa indonesia bagi penutur asing. AKSIS: Jurnal Pendidikan Babasa dan Sastra Indonesia, 1(2), 204-220. http://doi.org/10.21009/AKSIS 
Jurnal Pendidikan Bahasa dan Sastra, Volume 21, Nomor 1, April 2021, pp. 25-36 